\title{
UPAYA PENINGKATAN PEMEREKAN ORGANISASI BERBASIS DARING MELALUI PELATIHAN MENGEMBANGKAN MEDIA SOSIAL RPTRA DHARMA SUCI
}

\author{
Michael Christian \\ Universitas Bunda Mulia \\ Email: michaelchristianid@gmail.com
}

\begin{abstract}
The regulation of the Governor of DKI Jakarta Number 196 (2015) on Child Friendly Integrated Public Space (RPTRA) explains the open areas for children that can be a positive medium for interaction and play. The development of RPTRA in DKI Jakarta is not fully funded by the DKI Jakarta government through the Regional Government Expenditure Budget (APBD), but the program also involves companies in the form of Corporate Social Responsibility (CSR). In terms of marketing, this synergy program can not only strengthen the organizations/companies involved in the CSR program but indirectly can help the existing RPTRA to more easily introduce the implementation of its activities through branding. The concept of branding for the organization is not an easy thing not only for the surrounding community as RPTRA's board but also for marketers. Social networking sites can be a powerful medium in developing RPTRA as an organizational brand that makes marketing communications have a significant influence on how organizations communicate to their customers. This study aims to measure the effectiveness of training on the role of social media to improve online organization. The method used by observation measurement at two periods (before and after training) and the effectiveness of training provided (using SPSS 22.0). The result of this training is able to explain the increasing effectiveness of the use of social media RPTRA Dharma Suci and utilization of supporting media elements in it such as photos, videos and so on. Suggestions for further research may consider the use of other social medias and observations over a longer time span.
\end{abstract}

Keywords: RPTRA, branding, organization, social media

\begin{abstract}
ABSTRAK: Peraturan Gubernur (Pergub) Provinsi DKI Jakarta Nomor 196 Tahun 2015 tentang Ruang Publik Terpadu Ramah Anak (RPTRA) dapat menjelaskan kawasan terbuka untuk anak dapat menjadi media positif untuk berinteraksi dan bermain. Pembangunan RPTRA di DKI Jakarta yang tidak sepenuhnya dibiayai oleh pemerintah DKI Jakarta melalui Anggaran Pemerintah Belanja Daerah (APBD), namun program ini juga melibatkan perusahaan-perusahaan dalam bentuk Corporate Social Responsibility (CSR). Dari sisi pemasaran, program bersinergi ini tidak hanya dapat memperkuat organisasi/perusahaan yang terlibat dalam program CSR tersebut tetapi secara tidak langsung dapat membantu RPTRA yang ada untuk lebih mudah dalam memperkenalkan pelaksanaan kegiatannya melalui upaya branding (pemerekan). Konsep pemerekan bagi organisasi bukan hal yang mudah tidak hanya bagi komunitas penduduk sekitar sebagai pengurus RPTRA tetapi juga berlaku bagi para pemasar. Situs-situs jejaring sosial tesebut dapat menjadi media yang ampuh dalam mengembangkan RPTRA sebagai suatu merek organisasi yang menjadikan komunikasi pemasaran memiliki pengaruh signifikan terhadap cara organisasi berkomunikasi kepada pelanggannya. Penelitian ini bertujuan untuk mengukur efektivitas pelatihan mengenai peran media sosial untuk meningkatkan pemerekan organisasi berbasis daring. Metode yang digunakan dengan melakukan pengukuran observasi pada dua periode (sebelum dan sesudah pelatihan) dan efektivitas pelatihan yang diberikan (menggunakan SPSS 22.0). Hasil dari pelatihan ini mampu menjelaskan terjadi peningkatan efektivitas penggunaan media sosial RPTRA Dharma Suci dan pemanfaatan unsur media pendukung di dalamnya seperti media foto, video dan sebagainya. Saran untuk penelitian selanjutnya dapat mempertimbangkan penggunaan muti media sosial dan observasi dengan rentang waktu yang lebih panjang.
\end{abstract}

Kata Kunci: RPTRA, pemerekan, organisasi, media sosial 


\section{Pendahuluan}

Melihat pada Peraturan Gubernur (Pergub) Provinsi DKI Jakarta Nomor 196 Tahun 2015, Ruang Publik Terpadu Ramah Anak (RPTRA) dapat diartikan sebagai kawasan dan/atau ruang terbuka yang memadukan kegiatan dan aktivitas penduduk lokal untuk mencipakan program Kota Layak Anak (www.jakarta.go.id, 2015). Berdasarkan laporan dari www.jakarta.go.id, dilihat bahwa ketersediaan RPTRA sampai bulan Maret 2017 terdapat sebanyak 184 titik RPTRA dan terus diupayakan untuk ditambah.

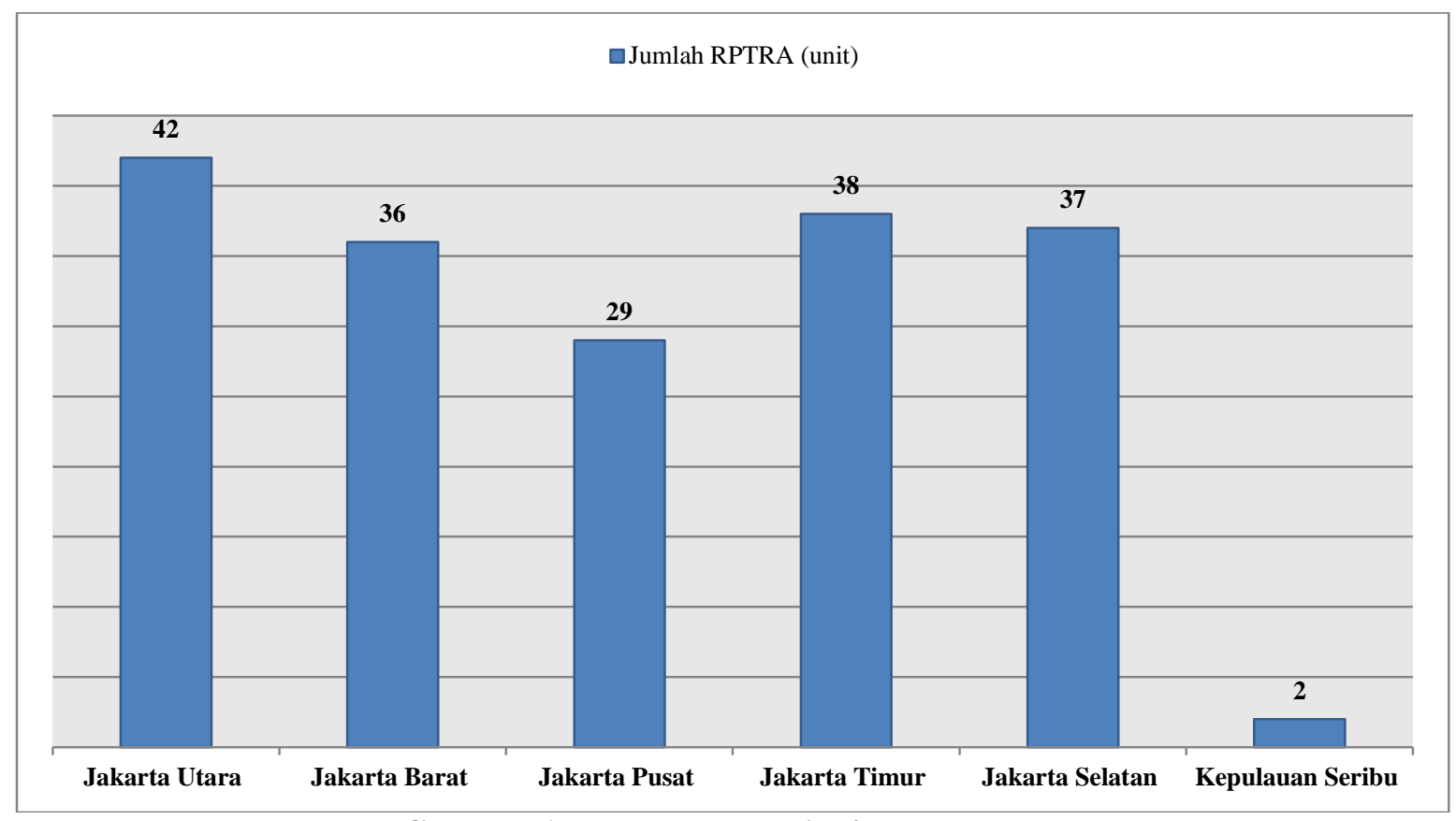

Gambar 1. Jumlah RPTRA di DKI Jakarta Sumber: www.jakarta.go.id (2015)

Dengan terus diupayakannya penambahan jumlah RPTRA di DKI Jakarta dapat menjelaskan kawasan terbuka untuk anak dapat menjadi media positif untuk berinteraksi dan bermain. Dan program RPTRA ini dapat menjadi salah satu program unggulan pemerintah DKI yang dapat menjadi program percontohan bagi wilayah lain di Indonesia. Pembangunan RPTRA di DKI Jakarta ternyata tidak sepenuhnya dibiayai oleh pemerintah DKI Jakarta melalui Anggaran Pemerintah Belanja Daerah (APBD), namun program ini juga melibatkan perusahaan-perusahaan dalam bentuk Corporate Social Responsibility (CSR). Dari data tersebut sebanyak 123 RPTRA dibangun dengan biaya yang berasal dari APBD dan 61 RPTRA dibangun dengan pendanaan CSR.

Keterlibatan organisasi/perusahaan seperti: Nestle, Intiland, Ciputra, Agung Sedayu, dan Dharma Suci dalam program CSR RPTRA ini menjadi fenomena yang menarik untuk dibahas. Hampir setiap perusahaan khususnya yang berskala besar memiliki program CSR yang secara periodik dilakukan. RPTRA dalam hal ini mampu mewakili kebutuhan masyarakat yang menjadi lingkup CSR bagi perusahaan. Dari sisi pemasaran, program bersinergi ini tidak hanya dapat memperkuat organisasi/perusahaan yang terlibat dalam program CSR tersebut tetapi juga secara tidak langsung dapat membantu RPTRA yang ada lebih mudah dalam memperkenalkan pelaksanaan kegiatannya melalui upaya branding (pemerekan). Hal ini yang perlu ditekankan pada setiap RPTRA khususnya yang memiliki organisasi/perusahaan sebagai penyokongnya. Pemerekan tersebut tidak lagi dilihat sebagai produk organisasi/perusahaan penyokong tetapi diarahkan kepada pelaksanaan program RPTRA yang ada di masing-masing kawasan.

Konsep pemerekan bagi organisasi bukan hal yang mudah tidak hanya bagi komunitas penduduk sekitar sebagai pengurus RPTRA tetapi juga berlaku bagi para pemasar. Selama bertahun-tahun, pemerekan organisasi telah ada sebagai alat yang strategis dalam 
membentuk dan mempertahankan daya saing dengan melakukan pergeseran paradigma fokus dari merek yang bersifat individu ke arah merek organisasi (Sandada \& Finch, 2015). Padahal komunitas yang terbentuk dari penduduk lokal secara tidak langsung dapat mendorong perkembangan wilayah sekitar (Montoya, 2013).

Sangat disayangkan beberapa titik RPTRA dinyatakan belum layak dalam pengelolaannya. Masih ditemukannya beberapa hal seperti pagar yang jebol dan penyalahgunaan air dan listrik (Ramadhan, 2016) dan kumuhnya kawasan RPTRA akibat penyalahgunaan fungsi untuk kepentingan beberapa pihak (Herudin, 2017). Dalam hal ini, media komunikasi turut berperan menjembatani reputasi dari masing-masing RPTRA yang ada. Oleh karena itu sebaiknya media komunikasi baik yang bersifat di luar jaringan (luring) dan daring dapat meningkatkan reputasi RPTRA melalui program-program yang dilaksanakan, seperti RPTRA di Jakarta Utara menjadi RPTRA terbaik tahun 2016 (Wandi, 2016) atau program RPTRA DKI Jakarta menjadi 15 besar inovasi dunia (Purnamasari, 2017).

Keberhasilan program RPTRA seperti di atas, salah satunya dapat diwujudkan dengan publikasi profil RPTRA yang ada dengan segala kegiatan yang dilakukan. Dalam hal ini peran media menjadi penting untuk digunakan. Perilaku dalam sosial dan cara berpikir yang sebelumnya dipengaruhi oleh media-media konvensoinal seperti televisi, radio dan surat kabar sekarang sudah bergeser kepada media sosial berbasis dalam jaringan atau dikenal dengan istilah daring (Duffet, 2017). Jejaring sosial bukan lagi menjadi fenomena baru karena dewasa ini sudah melekat pada masyarakat dalam bersosialisasi dan berkomunikasi (Uitz, 2012). Menurut data dari www.statista.com, situs jejaring sosial Facebook masih mengungguli Twiiter dilihat dari jumlah pengguna aktif di seluruh dunia.

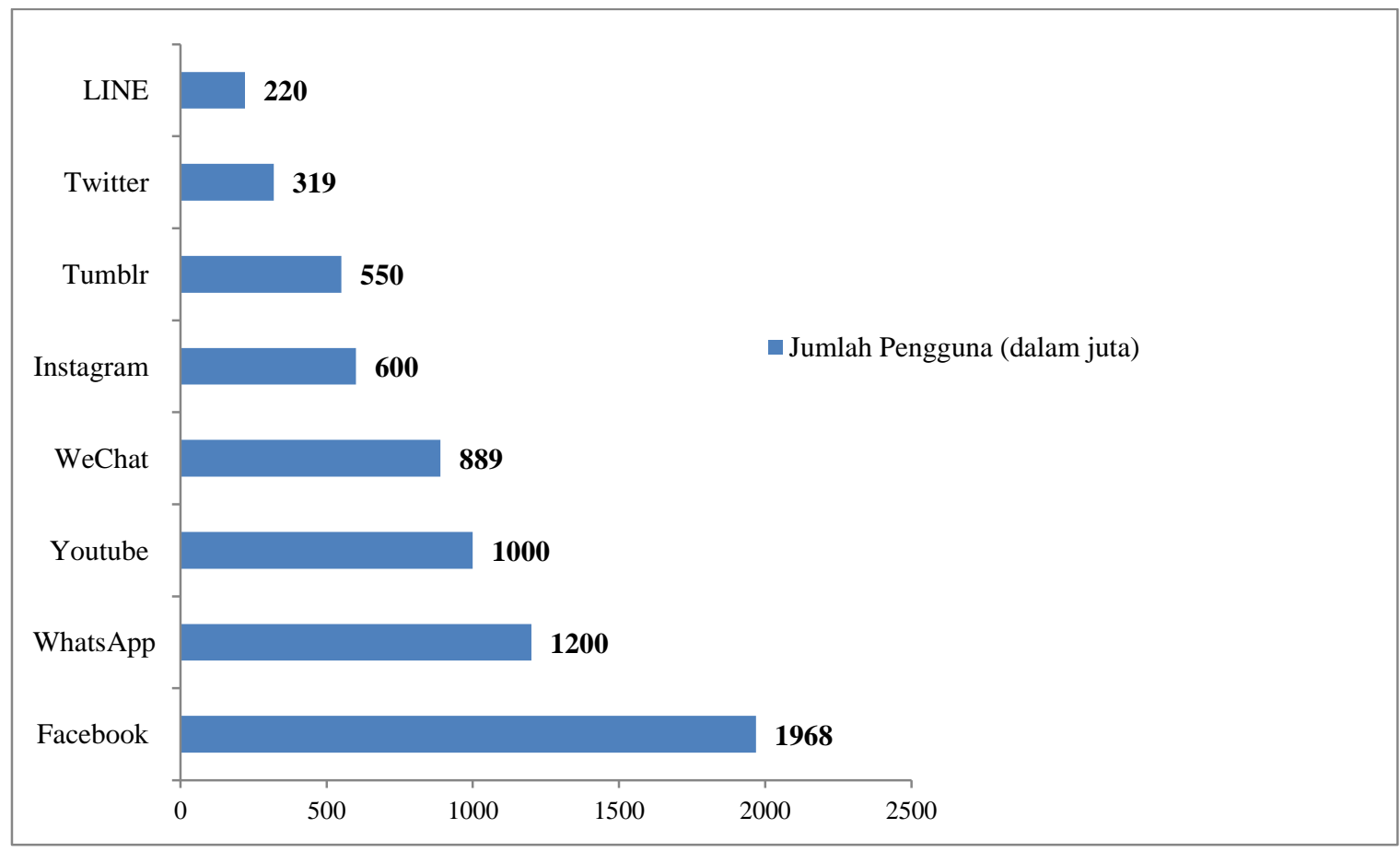

\section{Gambar 2. Jejaring Sosial Berdasarkan Jumlah Pengguna Aktif di Seluruh Dunia Sumber: https://www.statista.com, 2017}

Situs-situs jejaring sosial tesebut dapat menjadi media yang ampuh dalam mengembangkan RPTRA sebagai suatu merek organisasi yang menjadikan komunikasi pemasaran memiliki pengaruh signifikan terhadap cara organisasi berkomunikasi kepada pelanggannya (Duffet, 2017). Dalam hal ini komunikasi pada media tidak hanya ditujukan bagi para pengurus atau anggota saja, namun juga kepada masyarakat. Ini akan mencerminkan seberapa kuat RPTRA tersebut dikenal masyarakat dalam melaksanakan profil 
tugas dan tanggung jawabnya sebagai suatu organisasi. Oleh karena itu perlu dilakukan identifikasi yang dalam hal ini RPTRA mengenai eksistensi pemerekannya sebagai suatu organisasi sekaligus pemberian solusi dalam bentuk pelatihan untuk meningkatkan pengetahuan dan wawasan mengenai peran serta media sosial dalam eksistensi RPTRA sebagai suatu organisasi.

\section{TINJAUAN PUSTAKA}

\section{Pemerekan Organisasi}

Pemerekan perusahaan (organisasi) merupakan pendekatan manajemen merek yang diadposi oleh organisasi untuk membuat identitas organiasasi yang unik (Abratt \& Kleyn, 2011). Gregory (2004) menjelaskan bahwa pemerekan organisasi bukanlah mengenai produk, kampanye, logo, figur, atau slogan. Lebih dari itu, pemerekan organisasi adalah mengenai jutaan pengalamann suatu organisasi membangun (baik dengan pekerja, vendor, investor, reporter, komunitas dan pelanggan) perasaan yang emosional. Pemerekan organisasi yang kuat mampu membentuk, mengatur, dan memenuhi ekspektasi yang tinggi bagi para penggunanya dengan cara menyesuaikan produk, layanan, dan budaya menjadi suatu pertimbangan dalam setiap pengambilan keputusan. Sandada \& Finch (2015) menjelaskan bahwa pemerekan organisasi dapat dilhat dari unsur-unsur pembentuknya yaitu misi organisasi, budaya organisasi, komunikasi organisasi, identitas organisasi, tinjauan identitas organisasi. Khsususnya dalam unsur komunikasi organisasi, komunikasi berbasis daring dengan media tertentu dapat digunakan sebagai alat pengukur.

\section{Media Sosial}

Media sosial dapat dijelaskan sebagai satu bentuk aplikasi dengan berbasis internet dari konsep situs generasi 2.0 yang berfungsi untuk membuat atau bertukar konten sesama pengguna (Kaplan \& Haenlein, 2010). Sedangkan Aral, Dellarocas, \& Godes (2013) menjelaskan bahwa media sosial pada dasarnya merupakan media perubahan daam cara berkomunikasi, bekerja sama, menerima informasi, dan membuat informasi. Bugshan, Hajli, Lin, Featherman, \& Cohen (2014) menyatakan bahwa media sosial merupakan media populer bagi pengguna dalam berinteraksi satu dengan yang lain dan juga dalam hal pertemanan secara daring.

Golbeck (2013) menjelaskan bahwa alasan penggunaan media sosial bagai sektor publik seperti organisasi ataupun agensi memiliki 3 tipe yang berbeda yaitu penyampaian informasi dengan pengikut/teman, media umpan balilk dalam bentuk komentar dari postingan tertentu, menjadi media interaksi diskusi antara sesama pengikut. Melalui publikasi postingan di media sosial, perusahan dapat meningkatkan interaksi pengguna dan pelanggan yang potensial (Coelho, de Oliveira, \& de Almeida, 2016) dan jua pendekatan yang dilakukan oleh Bernritter, Verlegh, \& Smit (2016). Hal tersebut akan diperoleh setelah membentuk profil organisasi melalui kumpulan berita, foto dan video yang dapat dijelaskan juga dengan pengukuran dalam media sosial berbasis daring. Lebih lanjut juga dijelaskan dalam penelitiannya bahwa beberapa indikator berbentuk kuantitatif dan kualitatif dapat digunakan untuk menjelaskan pengaruh konten pada media sosial seperti Facebook dan Instagram.

Tabel 1 Faktor Pengukuran Konten di Media Sosial

\begin{tabular}{lll}
\hline Faktor & Deskripsi & Bentuk \\
\hline Tanda suka & $\begin{array}{l}\text { Jumlah tanda suka yang didapat dari tiap } \\
\text { postingan }\end{array}$ & Kuantitatif \\
\hline Komentar & Jumlah komentar yang ada dari tiap postingan & Kuanititatif \\
\hline Iklan & $\begin{array}{l}\text { Postingan bersifat promosi merek atau bersifat } \\
\text { hiburan yang bertujuan untuk meningkatkan } \\
\text { tanda suka dan komentar }\end{array}$ & \\
\hline Penggemar & Katerlibatan postingan dari penggemar & Kualitatif \\
\hline Aktivitas Kegiatan & $\begin{array}{l}\text { Postingan yang berkaitan dengan hal-hal seperti } \\
\text { foto, video yang berkaitan dengan merek ataupun } \\
\text { sebaliknya }\end{array}$ & \\
\hline Informasi & $\begin{array}{l}\text { Konten yang berisikan aktivitas kegiatan, tempat, } \\
\text { kesempatan, tokoh /selebriti, yang berkaitan }\end{array}$ & \\
\hline
\end{tabular}




\begin{tabular}{lll}
\hline & langsung dengan merek atau sebaliknya & \\
\hline Promosi & $\begin{array}{l}\text { Postingan dengan unsur kuis denga hadia tertentu } \\
\text { yang melibatkan pengikut }\end{array}$ \\
\hline
\end{tabular}

Sumber: Coelho, de Oliveira, \& de Almeida (2016)

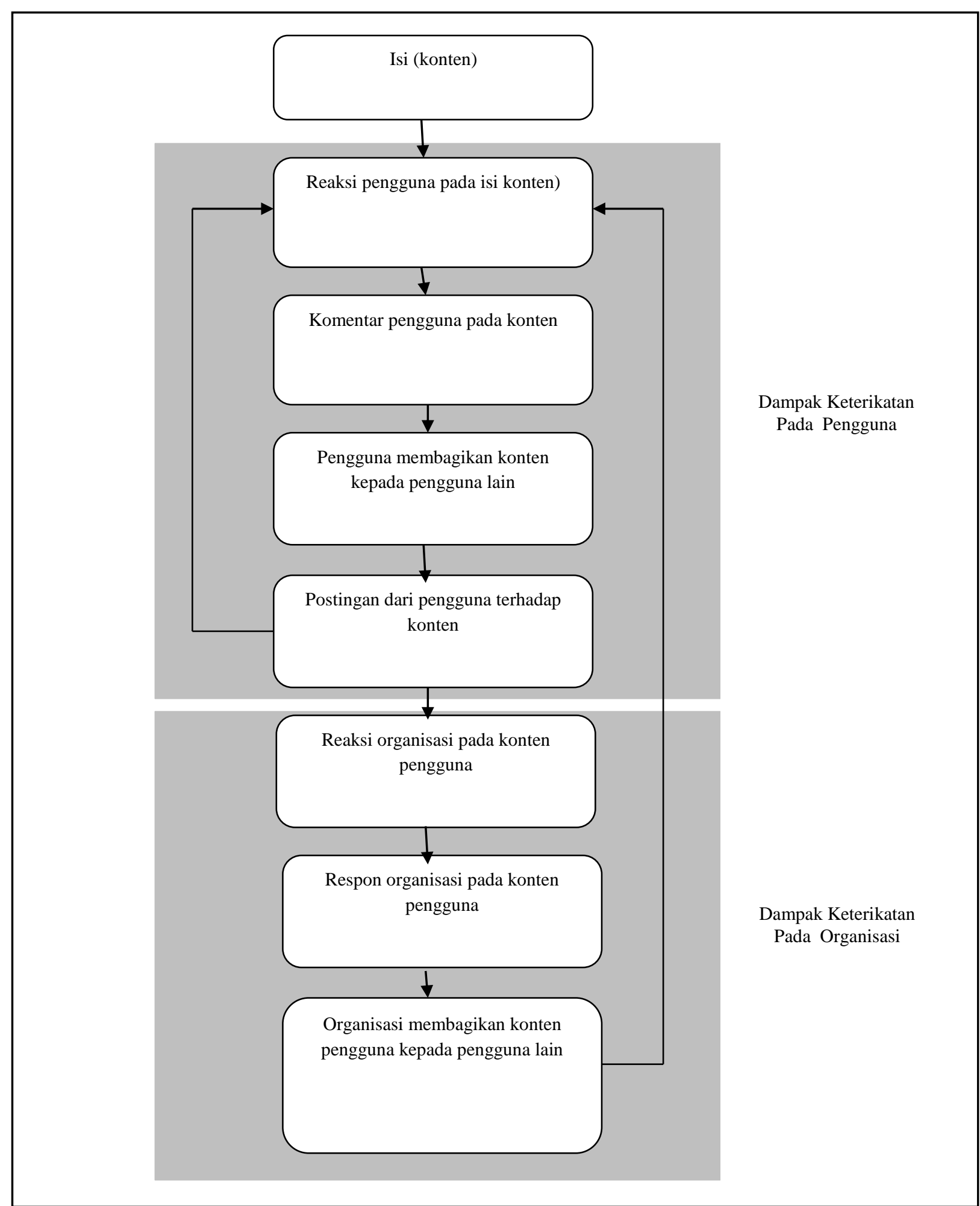

Gambar 3. Faktor Ukur Dampak Media Sosial Sumber: Barger, Peltier, \& Schultz (2016) 
Richards (2014 ) menjelaskan bahwa media sosial seperti facebook dan twitter dapat dijadikan sebagai media yang ampuh dalam mendukung tujuan organisasi. Facebook berkembang menjadi media sosial yang paling populer di dunia baik di seluruh lapisan kelompok usia dan masyarakat. Paling tidak terdapat tiga pertimbangan penggunaan Facebook yaitu jumlah pengguna yang tidak diragukan, menjadi media promosi, media sosial yang sudah terbukti dalam penggunaan baik untuk jangka panjang, dan bisa membentuk target pengguna/pertemanan. Secara konsep pemerekan, Facebook dapat digunakan menjadi media yang potensial dengan memperhatikan beberapa hal berikut: bergabung sebanyak mungkin dengan grup untuk memungkinkan berbgai konten, melakukan pengaturan pada kegiatan dan aktivitas yang memungkinkan untuk mengundang teman bergabung, pengaturan pada konten postingan (100-250 karakter memiliki daya tarik $60 \%$ lebih kuat untuk disukai, dibagikan dan dikomentari), mulai menggunakan tautan konten yang diposting untuk mengarahkan pengguna lain berkunjung.

Selanjutnya Twitter yang merupakan media sosial terbesar kedua setelah Facebook yang memiliki keunikan yaitu penggunaan tanda pagar sebagai keunggulan dibandingkanmedia sosial lain. Twitter dapat dijadikan sebagai media pendukung tujuan suatu organisasi apabila mempertimbangkan hal-hal seperti: menentukan tujuan penggunaan twitter, memaksimalkan fungsi twitter sesuai dengan tujuan yang ditentukan, profil yang memiliki kata kunci yang kuat, memberikan informasi yang relevan pada akun twitter yang dibuat, cerminkan daya tarik untuk pengguna harus mengikuti, membentuk keterikatan dengan cara mengikuti pengguna atau grup yang relevan dengan tujuan akun, meningkatkan kreativitas dalam melakukan postingan konten sepeti penggunaan foto dan video, konsistensi dalam melakukan postingn dan menggunakan tanda pagar yang disesuaikan dengan tren.

\section{Keterkaitan Media Sosial Dengan Pemerekan Organisasi}

Bagi organisasi khususnya pimpinan, penggunaan media komunikasi yang tepat menjadi faktor penting dalam efektivitas komunikasi internal (Lee, 2011), seperti pertemuan tatap muka, konferensi dengan menggunakan video atau kamera situs, telepon seluler dan konferensi dengan menggunakan telepon seluler, surat dengan suara, surat elektronik, pesan instan, dan juga media sosial (Roebuck, 2012). Karakter manajemen hubungan pelanggan yang memiliki karakter sosial memiliki tujuan, konsep, fokus dan konten tersendiri.

Tabel 2. Manajemen Hubungan Pelanggan Berkarakter Sosial

\begin{tabular}{ll}
\hline Deskripsi & Manajemen Hubungan Pelanggan Berkarakter Sosial \\
\hline Peran & Filosofi organisasi secara keseluruhan \\
\hline Sasaran & $\begin{array}{l}\text { Untuk mengatur komunikasi, nilai dari penciptaan strategi secara berkelanjutan, untuk } \\
\text { menciptakan keterikatan pelanggan dan pemangku kepentingan lain }\end{array}$ \\
\hline Konsep & Emosional dan perilaku \\
\hline Orientasi & Hasil yang lebih ringan diluar bisnis dan laba \\
\hline Tujuan & $\begin{array}{l}\text { Mengikat pelanggan dalam suatu interaksi demi terciptanya keuntungan mutualisme } \\
\text { dalam bentuk kepercayaan }\end{array}$ \\
\hline Fokus & Multi-Pemangku kepentingan \\
\hline Konten & Mengedepankan kepentingan informasi personal dengan dekripsi data pelanggan \\
\hline
\end{tabular}

Sumber: Lipiäinen (2015)

Schivinski, Christodoulides, \& Dabrowski (2016) menjelaskan bahwa konten publikasi dari organisasi hanya berpengaruh pada kesadaran/asosiasi pada merek saja, sedangkan konten yang dipublikasikan oleh pengguna memiliki pengaruh yang signifikan dalam pembentukan kesadaran/asosiasi merek, loyalitas pengguna, dan pengakuan kualitas pada merek. Sedangkan keterikatan pelanggan di media sosial dipengaruhi juga oleh faktor persepsi pelanggan itu sendiri, seperti sebagai hiburan (Azar, Machado, Vacas-de-Carvalho, $\&$ Mendes, 2016), penambahan informasi baru dan pengaruh/ikatan sosial (Berger, 2014; 
Azar, Machado, Vacas-de-Carvalho, \& Mendes, 2016), adanya promosi (Rohm, Kaltcheva, \& Milne, 2013; Azar, Machado, Vacas-de-Carvalho, \& Mendes, 2016), kesan organisasi kepada pelanggan (Rohm, Kaltcheva, \& Milne, 2013; Berger, 2014).

Schultz \& Peltier (2013) menjelaskan bahwa keterikatan yang terbentuk dapat dilihat dari berbagai konstruk hubungan seperti loyalitas pada merek, hubungan pemasaran, konsentris pemasaran, orientasi pemasaran, manajemen hubungan pelanggan, dan jaringan sosial. Melihat konstruk-konstruk tersebut , Hollebeek, Glynn, \& Brodie (2014) menyatakan bahwa keterikatan merekpelanggan dapat dijelaskan sebagai konsumen yang dihargai secara positif secara kognitif, emosi dan interaksi pada pelanggan/merek. Barger, Peltier, \& Schultz (2016) menjelaskan dalam keterikatan pelanggan pada merek paling tidak terdapat 6 faktor penting yaitu perilaku pada merek, brand warmth (tingkat kemampuan merek mampu meningkatkan emosi dan empati pengguna), kategori profit dan non profit, getok tular pada merek, iklan secara tradisional, dan komitmen berbasis teknologi komunikasi.

Tabel 3. Keterikatan Pelanggan Terhadap Merek

\begin{tabular}{|c|c|c|}
\hline Faktor & Keterikatan pada media sosial & Peneliti \\
\hline Perilaku pada merek & $\begin{array}{l}\text { Postingan viral seperti video pada media sosial } \\
\text { akan berdampak tidak hanya pada konten pada } \\
\text { video tersebut namun juga pada merek }\end{array}$ & $\begin{array}{l}\text { Huang, Su, Zhou, \& } \\
\text { Liu (2013) }\end{array}$ \\
\hline $\begin{array}{l}\text { Brand warmth, status } \\
\text { profit dan non profit } \\
\text { merek }\end{array}$ & $\begin{array}{llr}\text { Pengguna } & \text { akan } & \text { merekemondeasikan } \\
\text { (endorsement) hal-hal yang berkaitan } & \text { dengan } \\
\text { merek yang di publikasi di media sosial. } \\
\text { Pellanggan lebih berkeinginan untuk } \\
\text { merekomendasikan merek-merek yang bersifat } \\
\text { non profit dibandingkan yang memiliki kategori } \\
\text { profit. }\end{array}$ & $\begin{array}{l}\text { Bernritter, Verlegh, \& } \\
\text { Smit (2016) }\end{array}$ \\
\hline $\begin{array}{l}\text { Iklan } \\
\text { tradisional, } \\
\text { tular }\end{array}$ & $\begin{array}{l}\text { Peningkatan pada iklan akan terjadi seiring } \\
\text { dengan menurunnya getok tular di media daring } \\
\text { walaupun secara hubungan kausal masih perlu } \\
\text { dikaji. Di sisi lain, dampak iklan secara } \\
\text { tradisional dinilai lambat dalam membentuk } \\
\text { keterikatan pelanggan }\end{array}$ & Feng \& Papatla (2011) \\
\hline Komitmen organisasi & $\begin{array}{l}\text { Komitmen organisasi dalam membangun strategi } \\
\text { pada media sosial diharapkan dapat memberikan } \\
\text { dampak pada terciptanya keterikatan pada merek }\end{array}$ & $\begin{array}{l}\text { Cummins, Peltier, } \\
\text { Dixon (2016) }\end{array}$ \\
\hline
\end{tabular}

Sumber: Barger, Peltier, \& Schultz (2016)

Selanjutnya keterikatan pelanggan juga dapat dijelaskan dari faktor konten yang dipublikasikan di media sosial. Huang, Su, Zhou, \& Liu (2013) menyatakan bahwa konten merupakan faktor utama dalam mengajak pelanggan membagi konten di media sosial khususnya pada konten-konten yang tidak bersifat komersil (Swani, Milne, \& Brown, 2013). Hal ini menjelaskan bahwa format konten memiliki kadar efek yang berbeda (de Vries, Gensler, \& Leeflang, 2012), seperti konten yang berbentuk foto yang lebih mudah dalam menciptakan tanda suka, komentar sampai dengan membagikan ke pengguna lain (Kim, Spiller, \& Hettche, 2015). Sedangkan Berger \& Iyengar (2013) menjelaskan bahwa pelanggan melakukan publikasi di media sosial disebabkan oleh 2 faktor yaitu pelanggan mempunyai waktu untuk menulis daripada membicarakannya dan melakukan publikasi menjadi motivasi peningkatan diri. Sosial media sendiri dalam menjelaskan jaringan sosial yang memengaruhi keterikatan dengan pelanggan ditentukan dari atribut hubungan sosial, hiburan, akses informasi, dan kemudahan penggunaan (Mortazavi, Esfidani, \& Barzok, 2014).

Komunikasi pemasaran berbasis daring dapat dilihat dari bentuknya seperti gambargambar grafis yang ditampilkan di situs dan pada perkembangannya memiliki unsur audio, video dan bentuk tenologi inovatif lainnya 
(Duffet, 2017). Menurut Stokes (2013), komunikasi pemasaran berbasis daring bertujuan untuk menciptakan kesadaran merek, membentuk hubungan pelanggan, promosi dalam bentuk komunikasi dua arah, bentuk layanan kepada pelanggan, membentuk loyalitas pada merek, membentuk getok tular, sampai kepada upaya peningkatan penjualan. Dalam hal ini, beberapa penelitian sebelumnya juga berhasil menjelaskan keterkatian aspekaspek yang berkaitan dengan penelitian ini.

Tabel 4. Penelitian Sebelumnya

\begin{tabular}{ll}
\hline Peneliti & Hasil Penelitian \\
\hline Duffet (2017) & Komunikasi pemasaran melalui media sosial memberikan pengaruh \\
& secara positif pada tiap konstruk yang digunakan terhadap remaja \\
Kumar, Bhaskaran, & Kampanye di media yang bersifat getok tular dapat meningkatkan \\
Mirchandani, \& Shah & perilaku dan respon dari konsumen secara kognitif dan memberikan \\
(2013) & pengaruh pada hubungan sosial \\
Tham, Croy, \& Mair & Getok tular yang terjadi pada media sosial media memang tidak sama \\
(2013) & kredibelnya dengan getok tular secara tradisional. Namun demikian, \\
& komunikasi pemasaran pada media sosial telah memiliki mekanisme \\
& tersendiri dalam mengatasi gap ini. \\
\hline
\end{tabular}

Sumber: data primer, 2017

\section{Metode Penelitian}

RPTRA yang digunakan sebagai objek penelitian adalah RPTRA Dharma Suci yag berlokasi di Pluit, Jakarta Utara. Penelitian ini menggunakan model keterikatan media sosial (Barger, Peltier, \& Schultz, 2016) dalam menganalisis pemerekan RPTRA. Peserta pelatihan (sampel) ini adalah para anggota dan pengurus RPTRA Dharma Suci yang memegang kendali dan peran dalam program RPTRA Dharma Suci dan juga media sosial RPTRA Dharma Suci. Teknik yang digunakan dalam melakukan analisis data penelitian ini

\section{Hasil Dan Pembahasan}

Berdasarkan tabel di bawah, dapat dijelaskan bahwa media sosial yang digunakan oleh RPTRA Dharma Suci yaitu Facebook, memiliki jumlah postingan sebanyak 52 (ratarata 3 postingan per bulan). Hal ini dapat menjelaskan bahwa tingkat keaktifan RPTRA Dharma Suci dalam melakukan postingan hanya 3 postingan per bulan. Tanda suka sebanyak 1.306 (rata-rata 26 tanda suka per postingan). Hal ini menjelaskann bahwa tiap adalah dengan menggunakan analisis obervasi tinjauan pada media sosial RPTRA, pemberian pelatihan di lapangan, dan observasi tinjauan setelah pelatihan. Untuk mengetahui efektivitas pelatihan yang diberikan maka penelitian ini menggunakan instrumen kuesioner yang dilakukan pada saat pelatihan diberikan yaitu pada tanggal 18 Maret 2017 dan dianalisis dengan SPSS 22.0. Metode analisis penelitian ini mengaitkan skema proses Bernritter, Verlegh, \& Smit (2016).

postingan menciptakan tanda suka sebanyak 26 tanda. Pemberian informasi berbentuk kalimat dan media foto memiliki angka 48 dari 51 postingan (rata-rata 1 informasi kalimat/foto per tiap postingan selama kurun waktu tersebut). Sedangkan postingan dengan menggunakan media video sama sekali tidak dilakukan. Hal ini menjelaskan bahwa tiap postingan telah disertai 1 kalimat informasi dan media foto namuan tidak demikian dengan video yang sama sekali tidak dimanfaatkan.

Tabel 5. Tinjauan Media Sosial Facebook RPTRA Dharma Suci (periode April 2016 - 10 Maret 2017)

\begin{tabular}{rcccccccccccccc}
\hline & \multicolumn{1}{c}{2016} & 11 & \multicolumn{1}{c}{2017} \\
Faktor & $\mathbf{0 4}$ & $\mathbf{0 5}$ & $\mathbf{0 6}$ & $\mathbf{0 7}$ & $\mathbf{0 8}$ & $\mathbf{0 9}$ & $\mathbf{1 0}$ & $\mathbf{1 1}$ & $\mathbf{1 2}$ & $\mathbf{0 1}$ & $\mathbf{0 2}$ & $\mathbf{0 3}$ & $\mathbf{0 4}$ & $\mathbf{0 5}$ \\
& 4 & 7 & 2 & - & 4 & 3 & 3 & 7 & 7 & 9 & 2 & 6 & 8 & 4 \\
\hline
\end{tabular}




\begin{tabular}{|c|c|c|c|c|c|c|c|c|c|c|c|c|c|c|}
\hline $\begin{array}{l}\text { Tanda suka } \\
\text { (like) }\end{array}$ & 71 & 114 & 20 & - & 50 & 151 & 88 & 99 & 386 & 186 & 71 & 213 & 248 & 154 \\
\hline Komentar & 4 & - & 3 & - & 5 & 41 & 2 & 6 & 25 & 11 & 7 & 15 & 14 & 10 \\
\hline Kalimat & ya & ya & ya & - & ya & уа & ya & ya & ya & ya & ya & ya & ya & ya \\
\hline Foto & ya & ya & ya & - & ya & ya & ya & ya & ya & ya & ya & ya & ya & ya \\
\hline Video & - & - & - & - & - & - & - & - & - & - & - & - & ya & - \\
\hline
\end{tabular}

\section{Sumber: data diolah penulis, 2017}

Berdasarkan data di atas, peneliti melakukan pelatihan sebagai upaya peningkatan RPTRA Dharma Suci dalam hal pemerekan organisasi. Pelatihan dilakukan dengan 2 bagian penting yaitu paparan penjelasan pentingnya media sosial dalam upaya meningkatkan pemerekan RPTRA Dharma Suci secara cakupan daring, dan yang kedua melakukan praktik langsung

Setelah proses penjelasan paparan dan praktik pelatihan, maka dilakukan pengumpulan umpan balik dari peserta terhadap aspek materi dan narasumber dengan instruen kuesioner. Besar angka mean (rata-rata) pada tabel yaitu berada pada 3,5-3,8 dimana menjelaskan bahwa secara rata-rata responden menjawab angka 3 (setuju) dan 4 (sangat setuju) pada rentang skala item dari kuesioner yang diberikan. Pada kolom median, angka 4 menjelaskan bahwa keseluruhan responden memiliki angka tengah sebesar 4 (sangat pada media sosial RPTRA Dharma Suci. Dalam proses pelatihan, terjadi interaksi tanya jawab sebagai wujud keingintahuan lebih dari para peserta. Proses penjelasan paparan menggunakan media powerpoint dengan memasukan bentuk media seperti gambar dan video untuk lebih menciptakan suasana yang lebih menarik.

setuju). Besar standar deviasi (SD) pada tabel di atas nilai 0 dimana menjelaskan bahwa data yang digunakan tidak homogen (masih memiliki kecenderungan setiap data berbeda satu sama lain). Nilai Standard Error of Mean masih berada apa angka di bawah 1 dimana dapat diartikann bahwa semakin kecil angka standar eror maka sampel yang digunakan semakin representatif. Dalam penelitian ini sampel masih dapat dikatakan mewakili keakurata sampel yang dipilih dari populasi yang ada.

Tabel 6. Umpan Balik Berdasarkan Materi \& Implementasi

\begin{tabular}{lllll}
\hline Item & Mean & Median & SD & $\begin{array}{l}\text { SE of } \\
\text { Mean }\end{array}$ \\
\hline Manfaat materi & 3,636 & 4,000 & 0,504 & 0,152 \\
Relevansi materi dengan tujuan & 3,636 & 4,000 & 0,674 & 0,203 \\
Ketepatan sarana \& media yang digunakan & 3,545 & 4,000 & 0,522 & 0,157 \\
Proses kegiatan & 3,636 & 4,000 & 0,504 & 0,203 \\
Penambahan pengetahuan/keterampilan & 3,636 & 4,000 & 0,674 & 0,140 \\
Kemampuan/penguasaan materi & 3,727 & 4,000 & 0,467 & 0,121 \\
Kemampuan menyampaikan materi & 3,818 & 4,000 & 0,404 & 0,152 \\
Kemampuan menggunakan metode yang tepat & 3,636 & 4,000 & 0,504 & 0,152 \\
Kemampuan menjawab pertanyaan & 3,636 & 4,000 & 0,504 & 0,152 \\
Kemampuan menciptakan suasana yang & 3,636 & 4,000 & 0,504 & 0,152 \\
mendukung & & & & \\
\hline
\end{tabular}

Sumber: data diolah penulis 2017

Langkah selanjutnya dilakukan observasi setelah proses pelatihan, dimana cut off dilakukan selama pertengahan Maret sampai dengan Mei 2017 sehingga analisis observasi dilakukan dalam kurun waktu 2, 5 bulan. Hasil data observasi disajikan pada tabel 7 . 
Tabel 7. Tinjauan Media Sosial Facebook RPTRA Dharma Suci (periode 25 Maret - Mei 2017)

\begin{tabular}{lccc}
\hline \multicolumn{1}{c}{ Keterangan } & $\mathbf{0 3}$ & $\mathbf{0 4}$ & $\mathbf{0 5}$ \\
\hline Postingan & 6 & 8 & 4 \\
Tanda suka $($ like $)$ & 213 & 248 & 154 \\
Komentar & 15 & 14 & 10 \\
Kalimat & ya & ya & ya \\
Foto & ya & ya & ya \\
Video & - & ya & - \\
\hline
\end{tabular}

Sumber: data diolah penulis, 2017

Berdasarkan tabel di atas, RPTRA Dharma Suci memiliki jumlah postingan sebanyak 14 (rata-rata 4 postingan per bulan). Hal ini dapat menjelaskan bahwa terjadi peningkatan keaktifan dalam melakukan postingan dalam periode 2 bulan. Tanda suka sebanyak 548 (rata-rata 39 tanda suka per postingan). Hal ini juga menjelaskan terjadi peningkatan tanda suka menjadi 39 dari sebelumnya sebanyak 26 tanda secara rata-rata per postingan. Pemberian informasi berbentuk kalimat dan media foto memiliki angka 13 dari 14 postingan (rata-rata 1 informasi kalimat/foto per tiap postingan selama kurun waktu tersebut) dimana menjelaskan hasil ini masih tetap sama dengan periode observasi sebelum pelatihan. Sedangkan postingan dengan menggunakan media video berhasil meningkat walaupun tidak signifikan yaitu berjumlah 1 postingan. Hal ini menjelaskan bahwa RPTRA Dharma Suci sudah memiliki kesadaran akan peran pentingnya penggunaa media video dalam meningkatkan pemerekan RPTRA Dharma Suci di media sosial. Bila melihat perbandingan dengan periode sebelum pelatihan, maka dapat dijelaskan bahwa dengan kurun waktu observasi yang lebih singkat, RPTRA Dharma Suci mampu meningkatkan upaya untuk lebih mengenalkan RPTRA Dharma Suci kepada orang lain baik pada saat adanya kegiatan rutin/kunjungan maupun tidak. 


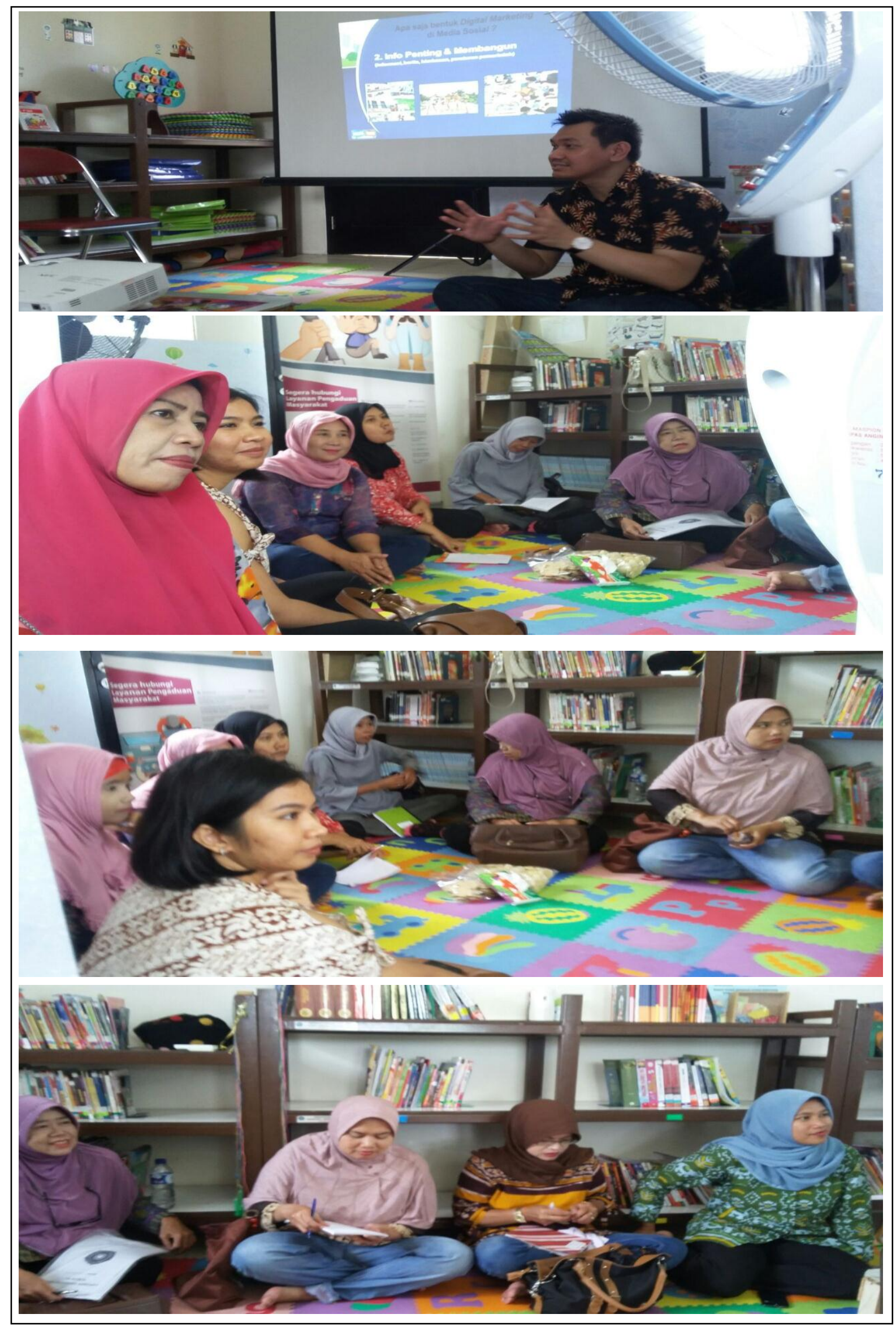

Sumber: data primer peneliti, 2017

Gambar 4. Pelatihan - Paparan \& Praktik Peranan Media Sosial 


\section{Simpulan Dan Saran}

Berdasarkan analisis dan pembahasan di atas, maka penelitian ini dapat disimpulkan bahwa media sosial memiliki peran yang penting dalam meningkatkan reputasi RPTRA Dharma Suci dalam hal pemerekan sebagai suatu organisasi. Konten-konten yang dipublikasi melalui postingan di media sosial tidak lagi hanya sebagai kalimat pemberi informasi saja namun sudah harus mempertimbangkan aspek hiburan dan daya tarik pengguna lain. Media media lain seperti pengunaan foto, video, peta juga dapat membantu dalam menciptakan keingintahuan pengguna lain untuk melihat, memberikan komentar, memberikan tanda suka atau bahan membagikan isi informasi tersebut pada media lain. Tingkat keaktifian sudah tercipta melalui publikasi dari segala kegiatan yang ada baik rutin, kunjugan pihak lain maupun ketika tidak ada kunjungan.

\section{Daftar Pustaka}

Abratt, R., \& Kleyn, N. (2011). Corporate identity, corporate branding and corporate reputations: reconcialiation and integration. European Journal of Marketing , 46 (7/8), 1048-1063.

Aral, S. S., Dellarocas, C., \& Godes, D. (2013). Introduction to the special issue - social media and business transformation: a framework for research. Information System Research, 24 (1), 3-13.

Azar, S. L., Machado, J. C., Vacas-deCarvalho, L., \& Mendes, A. (2016). Motivations to interact with brands on Facebook - towards a typology of consumer-brand interactions. Journal of Brand Management , 23 (2), 153-178.

Barger, V., Peltier, J. W., \& Schultz, D. E. (2016). Social Media And Consumer Engagement: A Review And Research Agenda. Journal of Research in Interactive Marketing , 10 (4), 268-287.

Berger, J. (2014). Word of mouth and interpersonal communication: a review and directions for future research. Journal
Saran dalam penelitian ini untuk peneliti berikutnya adalah dapat mempertimbangkan media sosial lain selain Facebook (multi media sosial) dimana dapat memberikan hasil perbandingan yang lebih variatif dan dapat dijadikan sebagai detektor karakteristik pembaca/pengguna informasi dari RPTRA yang ada. Selanjutnya dikarenakan periode observasi yang dilakukan kurang relatif panjang, maka sebaiknya dipertimbangkan untuk melakukan pengukuran setelah pelatihan dalam rentang waktu yang lebih lama (misalnya 6 bulan sampai 1 tahun). Hal ini bertujuan untuk lebih menjelaskan konsistensi tingkat keaktifan RPTRA dalam mengenalkan RPTRA dan kegiatan yang dilakukan.

of Consumer Psychology , 24 (4), 586607.

Berger, J., \& Iyengar, R. (2013). Communication channels and word of mouth: how the medium shapes the message. Journal of Consumer Research , $40(3), 567-579$.

Bernritter, S. F., Verlegh, P. W., \& Smit, E. G. (2016). Why nonprofits are easier to endorse on social media: the roles of warmth and brand symbolism. Journal of Interactive Marketing , 33, 27-42.

Bugshan, H., Hajli, M. N., Lin, X., Featherman, M., \& Cohen, I. (2014). Social media for developing health services. Qualitative Market Research: An International Journal , 17 (3), 283296.

Coelho, R. L., de Oliveira, D. S., \& de Almeida, M. I. (2016). Does social media matter for post typology? Impact of post content on Facebook and Instagram metrics. Online Information Review , 40 (4), 458-471.

Cummins, S., Peltier, J. W., \& Dixon, A. (2016). Omni-channel research framework in the context of personal 
selling and sales management: a review and research extensions. Journal of Research in Interactive Marketing , 10 (1), 2-16.

de Vries, L., Gensler, S., \& Leeflang, P. S. (2012). Popularity of brand posts on brand fan pages: an investigation of the effects of social media marketing. Journal of Interactive Marketing , 26 (2), 83-91.

Duffet, R. G. (2017). Influence of Social Media Marketing Communications on Young Consumer's Attitudes. Young Consumers , 18 (1), 19-39.

Feng, J., \& Papatla, P. (2011). Advertising: stimulant or suppressant of online word of mouth? Journal of Interactive Marketing , 25 (2), 75-84.

Golbeck, J. (2013). Analyzing The Social Web . Waltham : Morgan Kaufmann Elsevier .

Gregory, J. R. (2004). The Best of Branding. New York: McGraw-Hill.

Herudin. (2017 , April Selasa ). http://www.tribunnews.com. Retrieved Juni Selasa, 2017, from http://www.tribunnews.com: http://www.tribunnews.com/metropolita n/2017/04/25/berita-foto-tamankalijodo-jadi-kumuh-preman-merajelalapak-pkl-menjamur?page $=2$

Hollebeek, L. D., Glynn, M. S., \& Brodie, R. J. (2014). Consumer brand engagement in social media: conceptualization, scale development and validation. Journal of Interactive Marketing , 28 (2), 149-165.

https://www.statista.com. (2017, April). Retrieved Juni 16, 2017, from https://www.statista.com: https://www.statista.com/statistics/2720 14/global-social-networks-ranked-bynumber-of-users/

Huang, J., Su, S., Zhou, L., \& Liu, X. (2013). Attitude toward the viral ad: expanding traditional advertising models to interactive advertising. Journal of Interactive Marketing , 27 (1), 36-46.
Kaplan, A. M., \& Haenlein, M. (2010). Users of The World, Unite! The Challenges and Opportunities of Social Media. Business Horizons , 53 (1), 59-68.

Kim, D. H., Spiller, L., \& Hettche, M. (2015). Analyzing media types and content orientations in Facebook for global brands. Journal of Research in Interactive Marketing , 9 (1), 4-30.

Kumar, V., Bhaskaran, V., Mirchandani, R., \& Shah, M. (2013). Creating a measurable social media marketing strategy: increasing the value and ROI of intangibles and tangibles for hokey pokey. Marketing Science , 32 (2), 194212.

Lee, C. E. (2011). Computer-mediated Communication and Organisational Communication: The Use of New Technology In The Workplace. The Journal of The South East Asia Research Centre for Communication and Humanities , 3 (1), 1-12.

Lipiäinen, H. S. (2015). CRM in The Digital Age: Implementation of CRM in Three Contemporary B2B Firms. Journal of Systems and Information Technology, 17 (1), 2-19.

Montoya, M. J. (2013). Potential Futures for a Healthy City: Community, Knowledge, and Hope for the Sciences of Life. Current Anthropology , 54 (7), 45-54.

Mortazavi, M., Esfidani, M. R., \& Barzok, A. S. (2014). Influencing VSN users' purchase intentions. Journal of Research in Interactive Marketing , 8 (2), 102-123.

Purnamasari, D. M. (2017 , Juni Senin). http://www.beritasatu.com. Retrieved Juni Selasa, 2017, from http://www.beritasatu.com: http://www.beritasatu.com/megapolitan/ 434755-program-rptra-dki-masuk-15besar-inovasi-dunia.html

Ramadhan, L. (2016, Februari Rabu ). http://www.tribunnews.com. Retrieved Juni Selasa, 2017, from http://www.tribunnews.com: 
http://www.tribunnews.com/video/2016/ 02/03/tak-becus-urus-rptra-ahok-

lurahnya-harus-kita-diganti

Richards, M. (2014). Social Media: Dominating Strategies For Social Media Marketing With Twitter, Facebook, Youtube, Linked, And Instagram . Seatle : CreateSpace Independent Publishing Platform.

Roebuck, D. B. (2012). Communication Strategies For Today's Managerial Leader. United States of America: Business Expert Press .

Rohm, A., Kaltcheva, V. D., \& Milne, G. R. (2013). A mixed-method approach to examining brand-consumer interactions driven by social media. Journal of Research in Interactive Marketing , 7 (4), 295-311.

Sandada, M., \& Finch, H. (2015). The Impact of Corporate Branding Dimensions on Firm Performance: Evidence from the Zimbabwean Petroleum Industry. Economica, 11 (6).

Schivinski, B., Christodoulides, G., \& Dabrowski. (2016). Measuring consumers' engagement with brandrelated social-media content: development and validation of a scale that identifies levels of social-media engagement with brands. Journal of Advertising Research, 56 (1), 64-80.
Schultz, D. E., \& Peltier, J. W. (2013). Social media's slippery slope: challenges, opportunities and future research directions. Journal of Research in Interactive Marketing , 7 (2), 86-99.

Stokes, R. (2013). eMarketing: The Essential Guide to Marketing in a Digital World. Cape Town : Quirk Education.

Swani, K., Milne, G., \& Brown, B. P. (2013). Spreading the word through likes on Facebook. Journal of Research in Interactive Marketing , 7 (4), 269-294.

Tham, A., Croy, G., \& Mair, J. (2013). Social media in destination choice: distinctive electronic word-of-mouth dimensions. Journal of Travel \& Tourism Marketing , 30, 144-155.

Uitz, I. (2012). Social Media: Is It Worth The Trouble? Journal of Internet Social Networking and Virtual Communities, 1-14.

Wandi. (2016, Desember Rabu ). http://poskotanews.com. Retrieved Juni Selasa, 2017, from http://poskotanews.com: http://poskotanews.com/2016/12/14/jaka rta-utara-juara-gebyar-rptra/

www.jakarta.go.id. (2015). Retrieved Juni Selasa, 2017, from www.jakarta.go.id: http://www.jakarta.go.id/v2/produkhuku $\mathrm{m} /$ details/4714 